[CONTRIBUtions hrom the Chemical, laboratory of the University of WashINGTON.]

\title{
COLORIMETRIC STUDIES ON THE NATURE OF CHROMATE SOLUTIONS.
}

BY WILLIAM M. DEHN.

Received January 17, 1914.

During the past quarter of a century many investigations have been made to determine the constitution and equilibria of chromates in aqueous solution. The preponderance of evidence previously and now contributed strengthens the conclusion that the most important equilibrium may be expressed by the equation:

$$
\mathrm{H}_{2} \mathrm{Cr}_{2} \mathrm{O}_{7}+\mathrm{H}_{2} \mathrm{O} \rightleftarrows 2 \mathrm{H}_{2} \mathrm{CrO}_{4} \text {. }
$$

As will be shown in the following experiments, the colors ${ }^{1}$ of chromic acid, dichromates and chromates in solutions more dilute than $0.003 \%$ are identical, that is, at these concentrations, both the chromic acid and the dichromates are completely ${ }^{2}$ hydrolyzed, in accordance with the above equation. Furthermore, it will be shown that heat ${ }^{3}$ promotes the reversal of such reactions, therefore, since the effect of hydroxyl and hydrogen ions has long been known, we have the following simple view of chromate solutions: Concentration

$$
\left.\begin{array}{l}
\begin{array}{l}
\text { Heat } \\
\text { Acids }
\end{array}
\end{array}\right\} \begin{aligned}
& \left(\mathrm{CrO}_{3}\right)_{n} \rightleftarrows \mathrm{H}_{2} \mathrm{Cr}_{4} \mathrm{O}_{13} \rightleftarrows \\
& \mathrm{H}_{2} \mathrm{Cr}_{3} \mathrm{O}_{10} \rightleftarrows \mathrm{H}_{2} \mathrm{Cr}_{2} \mathrm{O}_{7} \rightleftarrows \mathrm{H}_{2} \mathrm{CrO}_{4}\left\{\begin{array}{l}
\text { Dilution } \\
\text { Cold } \\
\text { Alkalies }
\end{array}\right.
\end{aligned}
$$

These reactions are assumed to involve only hydrolytic equilibria; however, when chromic oxide is dissolved in water and alkalies in varied proportions, many equilibria may be involved as typified by:

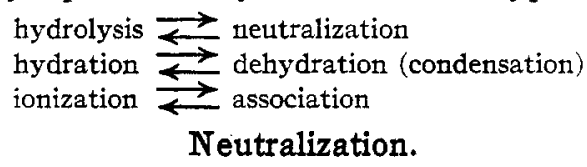

When chromic oxide is partially or fully neutralized with alkali, or is treated with an excess of the same (concentration and temperature remaining unchanged) the following reaction $\mathrm{s}^{4}$ are possible:

$$
\text { I }\left\{\begin{array}{l}
(a){ }_{12} \mathrm{CrO}_{3}+{ }_{3} \mathrm{KOH} \underset{12}{(b)} \underset{\mathrm{CrO}_{3}+6 \mathrm{KOHCH}}{\longleftrightarrow}{ }_{3} \mathrm{KH}_{2} \mathrm{Cr}_{4} \mathrm{O}_{13}+{ }_{3} \mathrm{H}_{2} \mathrm{O}
\end{array}\right.
$$

1 Ostwald ( $Z$. physik. Chem., 2, 78) states that the colors of chromic acid and of chromates are identical. This is true only in the concentrations stated above. Higher and equal concentrations of the two vary until the color of chromic acid is 2-3 times that of the dichromate.

${ }^{2}$ Moissan (Compt. rend., 98, 198; Ann. chim. phys., [6] 5, 568) doubted the existence of $\mathrm{H}_{2} \mathrm{CrO}_{4}$, so also did Field (Chem. Newes, 65, 153) and others.

${ }^{3}$ Hantzsch and Clark (Z. anorg. Chem., 63, 373) claim that light absorption of chromates is independent of heat, a conclusion which will be shown to be erroneous.

"Rammelsberg's hexachromate is very improbable. Ann., 94, 516. 


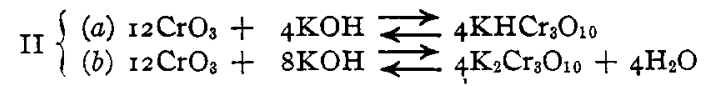

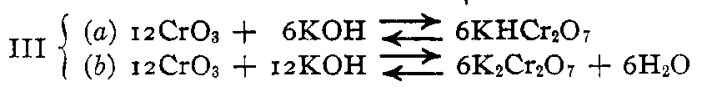

$$
\begin{aligned}
& \text { IV }\left\{\begin{array}{l}
(a){ }_{12} \mathrm{CrO}_{3}+{ }_{12} \mathrm{KOH} \\
(b){ }_{12} \mathrm{CrO}_{3}+24 \mathrm{KOH} \rightleftarrows \mathrm{I}_{2} \mathrm{KHCrO}_{4} \\
\mathrm{I}_{2} \mathrm{~K}_{2} \mathrm{CrO}_{4}+{ }_{12} \mathrm{H}_{2} \mathrm{O}
\end{array}\right.
\end{aligned}
$$

Here it is observed that with 12 molecules of chromic oxide: ( $\mathrm{I} a$ ) the minimum of alkali $(3 \mathrm{KOH})$ yields acid tetrachromate, which has not been isolated; (II $a$ ) an increase of alkali next yields acid trichromate, which also has not been isolated; (I $b$ ) and (III $a$ ) six molecules of alkali yield normal tetrachromate ${ }^{1}$ and acid dichromate, the latter of which has not been isolated; (II $b$ ) eight molecules of alkali yield normal trichromate; ${ }^{2}$ (III $b$ ) and (IVa) twelve molecules of alkali yield normal dichromate and acid chromate, the latter of which has not been isolated; (IVb) twenty-four or more molecules of alkali yield normal chromate. Since the acid chromates ${ }^{3}$ have not been prepared, and since the tetrachromates and trichromates are unstable in the presence of water, investigations of chromates in aqueous solutions have been directed mostly to chromic acid, the dichromates and the chromates. Though most investigations show that alkalies, ${ }^{4}$ dilutions and cold favor the formation of chromate, while acids, concentration and heat favor the formation of dichromate and chromic acid, intermediate products as $(x),(y)$ and $(z)$ may be involved, as indicated in the equation:

$$
\begin{aligned}
& \left.\begin{array}{l}
<\mathrm{H}_{2} \mathrm{O} \\
<\mathrm{HO}^{-} \\
>\mathrm{A}
\end{array}\right\} \longrightarrow\left(\mathrm{CrO}_{3}\right)_{n} \longleftrightarrow x \rightleftarrows \\
& \mathrm{H}_{2} \mathrm{Cr}_{2} \mathrm{O}_{7} \rightleftarrows y \rightleftarrows \mathrm{H}_{2} \mathrm{CrO}_{4} \rightleftarrows z \leftarrow\left\{\begin{array}{l}
>\mathrm{H}_{2} \mathrm{O} \\
>\mathrm{H}^{-} \\
<t
\end{array}\right.
\end{aligned}
$$

${ }^{1}$ Siewert, Z. ges. Naturw., 19, 15; Schwartz, Dingler's pol. J., 186, 31 ; Wyruboff, Bull. soc. chim., 35, 162; Darmstädt, Ber., 4, II7; Jäger and Krüss, Ber., 22, 2037 ; Rammelsberg, Ann., 94, 516.

2 See Siewert, Crookes, Jäger and Krüss, Bahr, Jahresberichte, I853, 358; Bothe, J. prakt. Chem., 46, 184; 60, 60; Stanley, Chem. News, 54, 194; Pries and Raymann, Ber., I3, 340; Wyruboff, Bull. soc. ind. min., 1880, 1882; Hauer, Sitzb. Akad. Wiss. Wien, 39, 439; Schroeder, Ann., I74, 249.

3 The improbable formation of acid chromate was mentioned by Walden, $Z$. physik. Chem., 2, 73.

${ }^{4}$ Studies of the solubilities of products of the above reactions, involving sodium, potassium and ammonium kations, in different concentrations of the corresponding alkali, presents an interesting point of attack of the problem of chromate structures. For instance, chromic oxide is very soluble in water; ammonium and potassium dichromate are less soluble, while sodium dichromate is more soluble than the corresponding chromates; finally, the chromates are less soluble in the presence of an excess of alkali. Therefore, at least two maxima of solubility are indicated when chromic acid ( $12 \mathrm{~mol} \mathrm{CrO}_{3}$ ) is dissolved in increasing quantities ( $\mathrm{I}-25 \mathrm{mols} \mathrm{MOH}$ ) of alkalies. If other maxima are found, other molecules than $\left(\mathrm{CrO}_{3}\right)_{2}, \mathrm{~K}_{2} \mathrm{Cr}_{2} \mathrm{O}_{4}$ and $\mathrm{K}_{2} \mathrm{CrO}_{4}$ will be indicated. Studies of this kind will be undertaken in this laboratory. 


\section{Hydrolysis.}

Since, as will be shown below, chromic oxide can yield by hydrolysis chromic acid of the formula $\mathrm{H}_{2} \mathrm{CrO}_{4}$, we may assume the following successive hydrolytic changes:

$$
{ }_{4} \mathrm{CrO}_{3} \longrightarrow \mathrm{H}_{2} \mathrm{Cr}_{4} \mathrm{O}_{13} \longrightarrow \mathrm{H}_{2} \mathrm{Cr}_{3} \mathrm{O}_{10} \longrightarrow \mathrm{H}_{2} \mathrm{Cr}_{2} \mathrm{O}_{7} \longrightarrow \mathrm{H}_{2} \mathrm{Cr}_{2} \mathrm{O}_{4}
$$

or as given in more detail:

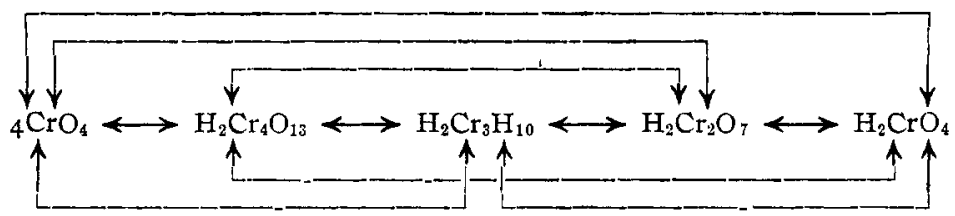

Since chromic acid and the alkali salts of the other four acids crystallize from solutions, it may be assumed that the molecules, constituting the masses separated, were assembled in solutions, hence existed, at least momentarily, in the solutions. The methods of preparation of chromic oxide and the polychromates, also the following colorimetric studies, corroborate this conclusion. Since all these reactions are reversible, aqueous solutions of chromic oxide may contain any or all of the above equilibria. Anhydrous solutions, as for instance, concentrated sulfuric acid, contain only chromic oxide; very dilute aqueous solutions (below $0.001 \%$ ) contain only $\mathrm{H}_{2} \mathrm{CrO}_{4}$; intermediate concentrations contain the other three-slightly acid solutions favor the formation of the dichromate, and successively increased acid solutions favor the higher poly-chromates.

The most probable assumption of the molecular complexity of chromic oxide is $4 \mathrm{CrO}_{3}$, for the following reasons: (I) four chromium atoms are found in tetrachromate, which is formed only in very concentrated solutions, while chromic oxide ${ }^{1}$ is formed from anhydrous solutions; (2) alternate linking of four atoms of oxygen with four atoms of chromium, forming a ring, would not be unstable in accordance with Baeyer's straintheory, whereas tri-, penta-, and higher molecular formulas would be unstable. If formula $(a)$ is assumed for the oxide, it is easy to see how one molecule of water attaches itself so as to form $(b)$ tetrachromic acid:

(a)<smiles>O=[14c]1o[14c](=O)o[14c](=O)[14c](=O)o1</smiles>

(b)<smiles>CCO[Cl+3]([O-])([O-])O[Cl+3]([O-])([O-])O[Cl+3]([O-])([O-])[O-]</smiles>

Also, it is easily seen how (b), by absorption of one, two, or three molecules of water, the lower chromic acids are formed:

${ }^{1}$ Kremann, Monatsh., 32, 6 19. 


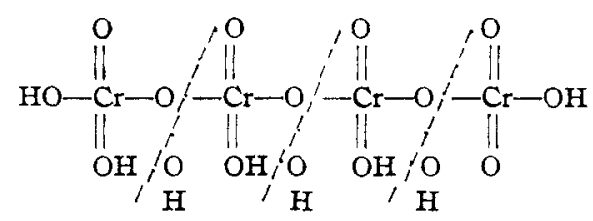

Here it is seen that tetrachromic acid-also chromic oxide-absorbs water and yields ( $\mathrm{I}$ ) four molecules of monochromic acid, (2) one molecule of dichromic acid and two molecules of monochromic acid, (3) one molecule of trichromic acid and one molecule of monochromic acid, or (4) two molecules of dichromic acid. The trichromic acid ${ }^{1}$ yields (I) three molecules of monochromic acid, or (2) one molecule of dichromic acid and one molecule of monochromic acid. The dichromic acid yields two molecules of monochromic acid. 'Thus with the tetrachromic acid, four hydrolyses are possible; with the trichromic acid, two; with the dichromic acid, one. But since trichromic acid, dichromic acid and their hydrolytic products are identical with the products of tetrachromic acid, only four hydrolytic equilibria are indicated. If we add to these the initial hydrolytic action on chromic oxide, and the hydrolyses of the salts of all these acids, and furthermore, if we consider the hydration products of all the above molecules and their respective ionization-equilibria, it is seen that complicated systems of equilibria are involved in solutions of chromates, in the presence of acids and alkalies, in different concentration and under the influence of heat, light, etc. Some of these are indicated in the table on the following page.

\section{Hydration.}

The following hydration-forms of monochromic acid may exist:

(a)<smiles>O=C(O)C(=O)O</smiles>

(b)<smiles>O=C(O)C(O)(O)O</smiles>

(c)<smiles>OC(O)(O)C(O)(O)O</smiles>

Dilution, cold and increase of alkali favor $a \longrightarrow c$; concentration, heat and decrease of alkali, $a \longleftarrow c$. These assumptions of hydration are supported by three lines of experimental evidence: ( $\mathrm{I}$ ) the quality of color of solutions, of less than $0.01 \%$ concentration, changes with greater dilution, ${ }^{2}$ (2) certain chromates crystallize with water $;^{3}(3)$ colorimetric studies of sensitiveness of color at these lower concentrations indicate two maxima. ${ }^{4}$

In respect to the first, in accordance with Beer's law and the teaching

1 Walden, $Z$. physik. Chem., 2, 73.

2 Vide infra. Also note application of Beer's law.

${ }^{3}$ Groger, $Z$. anorg. Chem., 70, 143; cf. Schulze, Ibid., Io, 154; Briggs, Ibid., 56, 254. For hydration addition-products of metallic dichromates, see Barbieri and Lanzoni, Atti accad. Lincei, I9, 584; 20, 1 19, II6I. Compare also: $\mathrm{Na}_{2} \mathrm{Cr}_{2} \mathrm{O}_{7} .2 \mathrm{H}_{2} \mathrm{O}$, $\mathrm{Na}_{2} \mathrm{CrO}_{4} \mathrm{IOH}_{2} \mathrm{O}, \mathrm{MgCrO}_{4} .7 \mathrm{H}_{2} \mathrm{O}$.

Am. Chem. J., 35, 255; 36, 198, 516. 


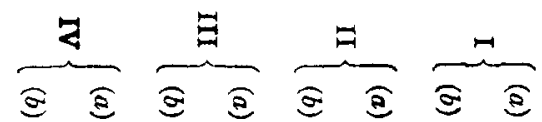

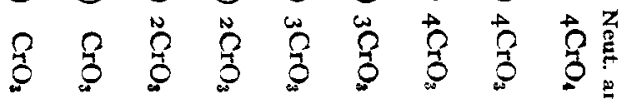

$+++++++++$

紊 不

$\uparrow \downarrow \uparrow \downarrow \uparrow \uparrow \uparrow \uparrow \uparrow \downarrow \uparrow \downarrow \uparrow \downarrow \uparrow$

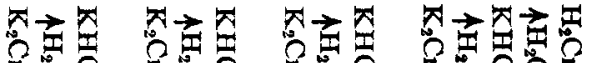

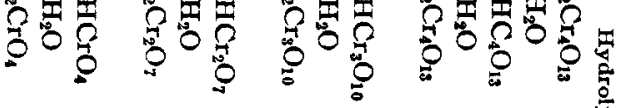

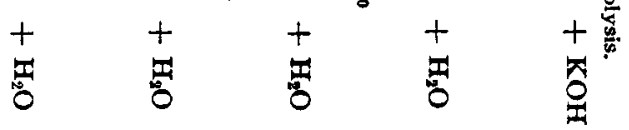

$\uparrow \downarrow \uparrow \uparrow \downarrow \uparrow \uparrow \downarrow \uparrow \downarrow \uparrow \uparrow \downarrow \uparrow \downarrow$

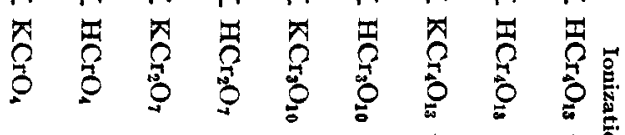

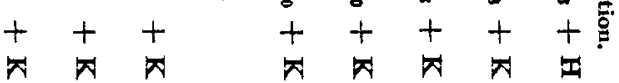

$\uparrow \downarrow \uparrow \uparrow \downarrow \uparrow \uparrow \downarrow \uparrow \uparrow \uparrow \uparrow$

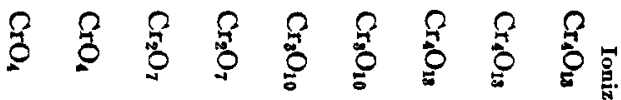

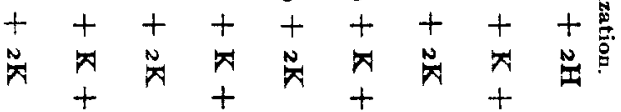

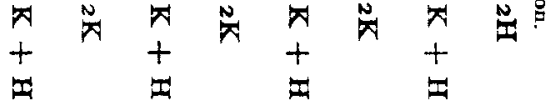


of Hantzsch, ${ }^{1}$ we would expect $(a),(b)$ and (c) above to represent three different chromophores and to give closely related but different colors. This is shown in the colors of low-concentrated solutions and is further supported by variations of color of hydrated chromates.

In respect to the second, Groger ${ }^{2}$ prepared five salts of the composition: (a) ${ }_{4} \mathrm{ZnO} . \mathrm{CrO}_{3} \cdot 3 \mathrm{H}_{2} \mathrm{O}$; (b) ${ }_{3} \mathrm{ZnO}_{2} \mathrm{CrO}_{3} .2 \mathrm{H}_{2} \mathrm{O}$; (c) ${ }_{4} \mathrm{ZnO} .2 \mathrm{CrO}_{3} \cdot 3 \mathrm{H}_{2} \mathrm{O}$; (d) $\mathrm{ZnO} .2 \mathrm{CrO}_{3} \cdot \mathrm{H}_{2} \mathrm{O}$; (e) $\mathrm{ZnO} \cdot \mathrm{CrO}_{3} \cdot \mathrm{H}_{2} \mathrm{O}$. These varied in color and were stable only in greater dilutions than $(a)$ o. $114,(b) 0.666,(c) 1.92,(d) 4.62$, (e) $4.62+$ molal concentrations, respectively. All these formulas can not only be made to conform to the above indicated hydration-forms of monoand di-chromic acid ${ }^{3}$ but, as was shown by Groger, the more complicated are stable only in the more dilute aqueous solutions. Furthermore, Groger ${ }^{4}$ found that $\mathrm{ZnCrO}_{4} \cdot \mathrm{H}_{2} \mathrm{O}$ contained, not water of crystallization, but water of composition. In respect to the third, Horn ${ }^{5}$ has shown that in colorimetric readings of solutions of potassium chromate in varied concentrations, two maxima of sensitiveness ${ }^{6}$ are found which he was unable to explain. These are shown in a curve ${ }^{7}$ and are indicated in the following condensed table:

$\begin{array}{ccrccc}\begin{array}{c}\text { G. at. wt. } \\ \text { Cr in l's. }\end{array} & \begin{array}{c}\text { Recalc. } \\ \text { as \% Cr. }\end{array} & \begin{array}{c}\text { Sensi- } \\ \text { tiveness. }\end{array} & \begin{array}{c}\text { G. at. Wt. } \\ \text { Crin l's. }\end{array} & \begin{array}{c}\text { Recalc. } \\ \text { as \% Cr. }\end{array} & \begin{array}{c}\text { Sensi- } \\ \text { tiveness. }\end{array} \\ 250 & 0.0208 & 0.07 & 8000 & 0.0006 & 250.00^{*} \\ 500 & 0.0104 & 0.34 & 9900 & 0.0005 & 50.00 \\ 667 & 0.0078 & 0.69 & 10667 & 0.0004 & 33.33 \\ 1000 & 0.0052 & 1.45 & 16000 & 0.0003 & 25.00 \\ 2000 & 0.0026 & 3.59 & 17700 & 0.0003 & 100.00 \\ 3600 & 0.0014 & 33.33 & 32000 & 0.00013 & 333.33^{*} \\ 4000 & 0.0013 & 100.00 & 110000 & 0.00005 & 25.00 \\ 7500 & 0.0007 & 100.00 & 150000 & 0.00003 & 33.33\end{array}$

Here it will be observed that the two maxima of sensitiveness are found far below the dichromate-chromate transition-concentration. ${ }^{8}$ An assumption of hydration could involve only two chromophoric changes and only two were found by Horn. Of course, had he carried his readings to higher concentrations he would have found other maxima, as at the transition-concentrations of $\mathrm{H}_{2} \mathrm{CrO}_{4} \rightleftarrows \mathrm{H}_{2} \mathrm{Cr}_{2} \mathrm{O}_{7} \rightleftarrows \mathrm{H}_{2} \mathrm{Cr}_{3} \mathrm{O}_{10}$, etc. $\mathrm{He}$

${ }^{1}$ Z. physik. Chem., 63, 367, 377 .

${ }^{2} Z$. anorg. Chem., 70, I35; see also Tbid., 54, 185 .

${ }^{3}$ See studies on the decomposition of hydrated ammonium salts, THrs Journal, 29, II 137 .

4. anorg. Chem., 70, 143 .

${ }^{5}$ Am. Chem. J., 35, 255; 36, 195, 516.

${ }^{8}$ Horn defines sensitiveness as the "reciprocal of the weight in milligrams of the colored solute that produces that change in color that can just be differentiated with certainty."

${ }^{7}$ Am. Chem. J., 36, 198.

${ }^{8}$ Vide infra. 
found only one maximum each for solutions of copper sulfate ${ }^{1}$ and ammoniacal copper sulfate. ${ }^{2}$ This is to be expected, ${ }^{3}$ since copper, a bivalent kation, could yield only two chromophores, the kation and the hydrated form.

In accordance with Weber's law of sensation, it is to be expected that solutions involving a single chromophore will require increased quantities of solute molecules to produce a definite sensation of change of color. Now, since Horn has demonstrated that, at certain concentrations, some solutions do not require logarithmic increments of colored solute molecules to produce a sensation of change, it may be assumed that: (r) the eye varies in sensitiveness for different concentrations or; (2) the eye functionates according to the logarithmic series and that the solutions themselves involve chromophoric changes. The latter hypothesis seems the more probable, since some solutions, ${ }^{4}$ for instance, solutions of potassium chromate containing much free alkali and in greater concentrations than studied by Horn, seem to follow Weber's law.

From the foregoing it seems safe to assume that hydration of colored molecules or colored ions produces chromophoric changes.

The hydration of chromates may yield only two forms; the polychromates may yield a greater number. Without involving hydrolysis or the formation of stereo-isomeric forms, it can be shown, theoretically, that dichromic acid may have five forms; trichromic acid, seventeen forms; tetrachromic acid, thirty-six forms; chromic oxide, nineteen forms. Of course, most of these seventy-seven forms are impossible since hydrolysis is more probable than hydration in most solutions-yet, since in most studies of chromate solution assumptions of hydration have been neglected, limited data have been taken, and contradictory conclusions have been drawn.

Investigations of solutions of chromic oxide, dichromates and chromates have been made by methods of electrical conductivities, ${ }^{5}$ cryoscopic

${ }^{1}$ Am. Chem. J., 36, 195.

2 Ibid., 36, 517 .

${ }^{3}$ An investigation of these solutions by the method of this contribution will be made.

${ }^{4}$ A search will be made in this laboratory for a strictly monochromic solution, $i . e$, one that conforms to Weber's law, and yields only one chromophore.

${ }^{5}$ Walden $(Z$. physik. Chem., I, 529; 2, 70) measured the conductance of chromate solutions at $25^{\circ}$ and found: that the salts of $\mathrm{H}_{2} \mathrm{Cr}_{2} \mathrm{O}_{7}$ are less stable but are better conductors than isomorphous sulfates; salts of $\mathrm{MHCrO}_{4}$ do not exist; di- and tri-chromates are hydrolyzed to dichromate and chromate. For further discussion of Walden's studies vide infra.

Whetham (Proc. Roy. Soc., 7I, 382) studied the conductance of $1 / 2 \mathrm{~K}_{2} \mathrm{Cr}_{2} \mathrm{O}_{7}$ at $0^{\circ}$ and obtained for molal concentrations of $0.0000 \mathrm{I}, 0.000 \mathrm{I}, 0.00 \mathrm{I}, 0.0 \mathrm{I}$ and 0.1 , respectively, $0.991,0.929,0.870,0.858$, and 0.783 -fractions of conductance at infinite dilution. Costa (Gazz. ital. chim., 36, 535) studied the conductance of chromic acid at $0^{\circ}$ and concluded that, in solutions not too concentrated, the formula is $\mathrm{H}_{2} \mathrm{Cr}_{2} \mathrm{O}_{7}$.

Lundberg ( 2 . anorg. Chem., 55, 426) found in $\mathrm{N} / \mathrm{ro}$ solution of $\mathrm{K}_{2} \mathrm{CrO}$ a $0.012 \%$ 
methods, ${ }^{1}$ ebullioscopic methods, ${ }^{2}$ optical absorption methods, ${ }^{3}$ colorimetric methods, ${ }^{4}$ speed of reaction with iodide-iodate solutions, ${ }^{5}$ speed of hydrolysis of ethyl acetate, ${ }^{6}$ of diazo acetic ester, ${ }^{7}$ catalysis of hydrogen peroxide, ${ }^{8}$ solubilities of difficultly soluble chromate salts, ${ }^{9}$ etc. ${ }^{10}$ All these methods, though invaluable, may involve errors of interpretation if recoghydrolysis and in $\mathrm{N} / \mathrm{IO}$ solution of $\mathrm{K}_{2} \mathrm{Cr}_{2} \mathrm{O}_{7}$ a $0.094 \%$ ionization as $\mathrm{HCrO}_{4} \rightleftarrows \mathrm{H}+$ $\mathrm{CrO}_{4}$.

Sherrill and Merrill (THis JourNaL, 29, 1650) measured the conductance of ammonium chromate in the presence of an excess of ammonium hydroxide and concluded that at $18^{\circ}$ in 0.0025 solution, chromic acid existed in the equilibrium:

$$
\mathrm{H}_{2} \mathrm{CrO}_{4} \rightleftarrows \mathrm{H}+\mathrm{HCrO}_{4} \text {. }
$$

${ }^{1}$ Ostwald (Z. physik. Chem., 2, 78) made cryoscopic molecular weight determinations of chromic acid and concluded that the formula is $\mathrm{H}_{2} \mathrm{Cr}_{2} \mathrm{O}_{7}$. He gives as confirmatory evidence for this conclusion: (a) salts like $\mathrm{K}_{2} \mathrm{CrO}_{4}$ are alkaline, whereas aqueous solutions of chromic acid are good conductors, $(b)$ the color of dichromates agrees completely with the color of aqueous solutions of $\mathrm{CrO}_{3}$. This latter statement is completely refuted by the experiments of this contribution.

Sherrill and Eaton (ThIS JouRnaL, 29, 1642) determined the van't Hoff factors for $\mathrm{K}_{2} \mathrm{Cr}_{2} \mathrm{O}_{7}$ and $\mathrm{H}_{2} \mathrm{Cr}_{2} \mathrm{O}_{7}$ in various concentrations.

2 Costa (Gazz. chim. ital., 36, 535) concluded that the formula of chromic acid in aqueous solutions is $\mathrm{H}_{2} \mathrm{Cr}_{2} \mathrm{O}_{7}$.

${ }^{8}$ Sttetegast (Wied. Ann., 7, 242). Hantzsch and Clark (Z. physik. Chem., 63, 367) studied absorption-spectra of various chromates and concluded that they are identical in cases of: (a) $\mathrm{CrO}_{3}+\mathrm{H}_{2} \mathrm{O} ; \mathrm{K}_{2} \mathrm{CrO}_{4}+\mathrm{H}_{2} \mathrm{SO}_{4} ; \mathrm{K}_{2} \mathrm{Cr}_{2} \mathrm{O}_{7}+\mathrm{H}_{2} \mathrm{SO}_{4} ;$ (b) $\mathrm{K}_{2} \mathrm{CrO}_{4}+\mathrm{H}_{2} \mathrm{O} ; \mathrm{K}_{4} \mathrm{CrO}_{4}+\mathrm{KOH} ; \mathrm{K}_{2} \mathrm{CrO}_{4}+\mathrm{CH}_{3} \mathrm{OH}$. Their experiments tended to show that $(a)$ and $(b)$ differed-in pure water the behavior of the dichromate diverges slightly in the direction of the chromate and vice versa. For further discussion of Hantzsch and Clark's data, see below.

${ }^{4}$ Horn and Blake $(A m$. Chem. J., 35, 253; 36, 195, 516$)$ made colorimetric studies of sensitiveness of reading of potassium chromate solutions. See discussion on pages following.

${ }^{5}$ Lundberg $(Z$. anorg. Chem., 55, 426) obtained data too irregular to enable them to decide between the two contested equations: $(a) \mathrm{CrO}_{4}^{--}+\mathrm{H}_{2} \mathrm{O} \longrightarrow \mathrm{HCrO}_{4}^{-}+\mathrm{OH}^{-}$, (b) ${ }_{2} \mathrm{CrO}_{4}^{--}+\mathrm{H}_{2} \mathrm{O} \longrightarrow \mathrm{Cr}_{2} \mathrm{O}_{7}+{ }_{2} \mathrm{OH}^{-}$.

${ }^{6}$ Sand and Kastle (Ibid, 52, IoI) concluded that at $25^{\circ}$ hydrolytic dissociation to the extent of $0.18 \%$ takes place according to the reaction: $\mathrm{Cr}_{2} \mathrm{O}_{7}+\mathrm{H}_{2} \mathrm{O} \longleftrightarrow$ ${ }_{2} \mathrm{CrO}_{4}+{ }_{2} \mathrm{H}$. See also Abegg and $\mathrm{Cox}$ (Ibid., 48, 425) who held that the $\mathrm{Cr}_{2} \mathrm{O}_{7}$ ion splits completely into $\mathrm{CrO}_{4}$ and $\mathrm{CrO}_{3}$ in solutions of moderate strength.

7 Spitalsky (Ibid., 53, 184; 54, 265;56, 72;69, 179).

8 Beck and Stegmüller (Z. Electrochem., 17, 843; Arb. Kais. Gesundheitsamt., 34, 446). Sherrill and Russ (This JouRnaI, 29, 166I) showed that at constant temperature the solubilities vary directly as the hydrogen ion except in the case of $\mathrm{PbCrO}_{4}$, which in concentrated solution was equal nearly to the square of the hydrogen ions.

9 Abegg and $\operatorname{Cox}(Z$. physik. Chem., 48, 725) maintain that hydrolytic dissociation to a limited extent takes place as follows: $\mathrm{Cr}_{2} \mathrm{O}_{7}+\mathrm{H}_{2} \mathrm{O} \longrightarrow 2 \mathrm{CrO}_{4}+2 \mathrm{H}$.

${ }^{10}$ For thermochemical investigations see Sabatier, Compt. rend., I03, 138, 267. Manchot (Ber., 36, 4305; 39, 1352, 3512) made oxidation experiments and concluded that the formula of chromic acid is 
nition of the influence of dilution, temperature, and quantities of acids or alkalies present, are not taken into consideration. The limitations of some of these investigations will be indicated in the following discussions.

\section{Method of Colorimetric Study.}

Solutions of $(a)$ chromic acid, (b) potassium dichromate, (c) potassium chromate, $(d)$ sodium chromate, $(e)$ potassium chromate plus one molecule of potassium hydroxide, $(f)$ potassium chromate plus six molecules of potassium hydroxide were put up in square, uniformly sized bottles of clear glass and $39 \mathrm{~mm}$. cross-section. ${ }^{1}$ Solutions were prepared in concentrations from saturation down to $0.000 \mathrm{I} \%$, calculated as $\mathrm{H}_{2} \mathrm{CrO}_{4}$. The respective tenths of the following concentrations were prepared:

$$
\text { Io, 1.0, 0.01, 0.001, 0.0001, 0.00001. }
$$

These percentage-concentrations, instead of fractional normal solutions, were prepared ( $\mathrm{I}$ ) because they gave a better basis of comparison than the latter, and (2) all the solutions in low and equal concentrations gave the same color-which is yellow and is assumed to be that of $\mathrm{H}_{2} \mathrm{CrO}_{4}$.

Any two series were compared and were found to differ in the upper ranges when concentrations were the same; or, by varying the concentrations of two series, colors could be matched evenly, thus indicating different tinctorial power for equal concentrations.

Only single bottles from the different series were matched, not only for the reason that the colors could usually be matched as closely as necessary, but for the more important reason that the method of reading the bottles in tandem of two or more involves errors. The most important observation of this contribution is that color-changes result from dilution of dichromates, etc. Therefore, when the tandem method is employed, the mass of solute-molecules, assumed to be the same when viewed in equalcolor solutions, really are contained in two or three volumes and since hydrolysis results, only approximate values are obtained. When necessary other concentrations than the ones indicated above were prepared. All the solutions were prepared with distilled water, and the very dilute solutions were prepared with ammonia-free water. The following series were prepared and compared at ordinary temperatures $\left(15^{-2} 5^{\circ}\right)$ :

$$
\begin{array}{rll}
\text { I. } & \mathrm{K}_{2} \mathrm{CrO}_{4}: & \mathrm{K}_{2} \mathrm{Cr}_{2} \mathrm{O}_{7} \\
\text { II. } & \mathrm{K}_{2} \mathrm{Cr}_{2} \mathrm{O}_{7}: & \mathrm{H}_{2} \mathrm{Cr}_{2} \mathrm{O}_{7}\left(\mathrm{CrO}_{2}+\mathrm{H}_{2} \mathrm{O}\right) \\
\text { III. } & \mathrm{K}_{2} \mathrm{CrO}_{4}: & \mathrm{K}_{2} \mathrm{CrO}_{4}+\mathrm{KOH} \\
\text { IV. } & \mathrm{K}_{2} \mathrm{CrO}_{4}: & \mathrm{K}_{2} \mathrm{CrO}_{4}+6 \mathrm{KOH}
\end{array}
$$

In Table I the first column gives the molar concentrations of the chromate; the second, the percentages of concentration of the chromate; the third, the percentage-concentration of the dichromate just matching the color of the chromate; the fourth, the ratio of concentration of the

${ }^{1}$ See This Journal, 36, 407 (1914). 


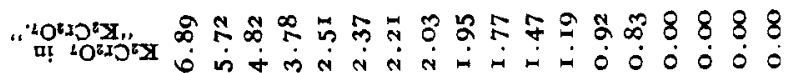

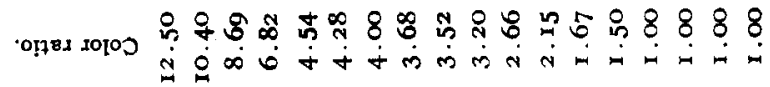

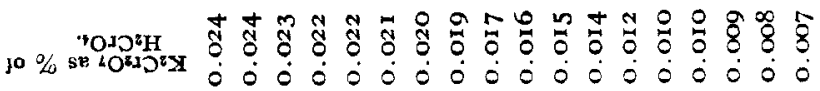

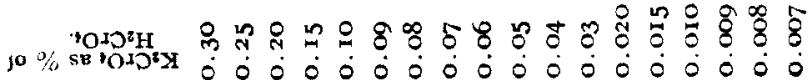

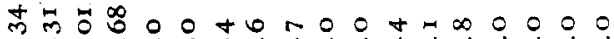

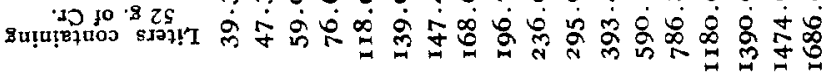

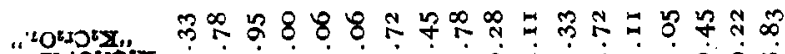

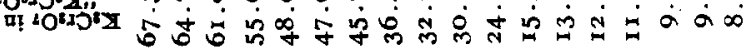

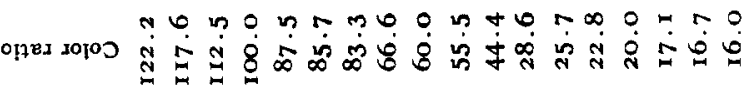

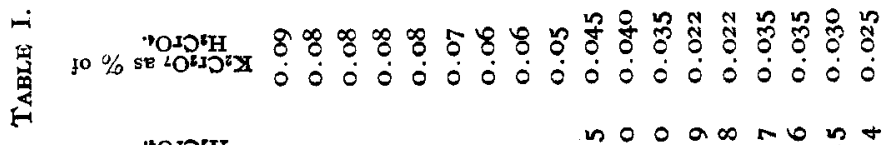

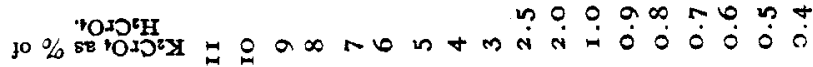

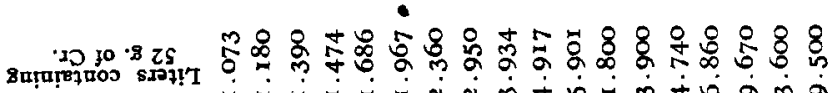

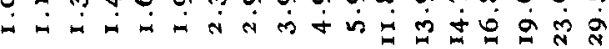

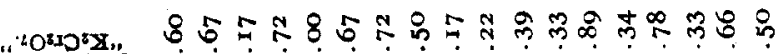
प!

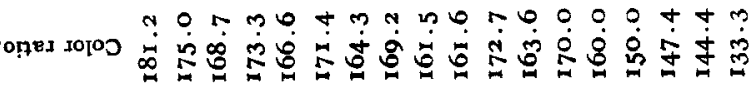

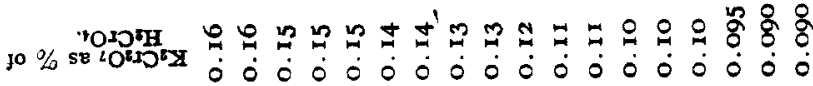

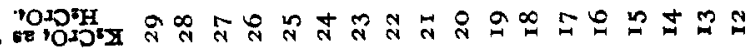

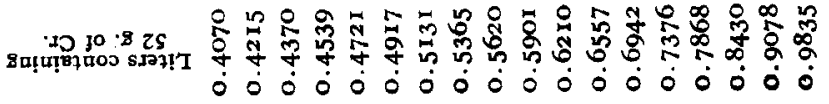


chromate and the dichromate; the fifth, the calculated per cent. of dichromate which really is in the chromophoric form $\mathrm{K}_{2} \mathrm{Cr}_{2} \mathrm{O}_{7}$.

It may be observed in the table that: ( $\mathrm{I}$ ) in concentrations below 0.or \%, the compared solutions are identical in color, which is some shade of yellow; (2) above this concentration the color of the dichromate becomes tinged with red, while the chromate remains yellow; (3) at higher concentrations both solutions are tinged with red but differ widely in intensity of color, as is shown by the different concentrations necessary to duplicate the colors.

The color ratio was obtained by dividing the respective concentrations of dichromate by the corresponding color-matched concentrations of chromate. Thus, for instance, $29 \%$ of the latter possesses the same color as a $0.16 \%$ solution of the former, a ratio of concentration equal to 18 I. I : 1 . If it is assumed that only two chromophores are present:<smiles></smiles><smiles>CCOC(=O)OC(=O)O</smiles>

then the latter is I8r.I times as intensely colored as the former. That this maximum color-ratio is nearly correct for concentrated solutions was corroborated by diluting a solution of $68 \mathrm{~g}$. of sodium chromate to IoO cc. and finding that it $\left(48.54 \% \mathrm{H}_{2} \mathrm{CrO}_{4}\right)$ was matched by a $0.27 \%$ solution of potassium dichromate, a color-ratio of 183.5 ; also by a $0.2 \%$ solution of chromic acid or a color-ratio of 247.7 . If it is assumed that the chromate-dichromate ratio is 180 , from the data obtained, actual quantities of chromate and dichromate in the "dichromate" solutions can be calculated. Since at certain concentrations (as below o.or \%) of both chromate and dichromate the colors are identical, ${ }^{1}$ it may be assumed that the chromium present in both is in the same chromophoric form. But if all the chromate at these low concentrations were transformed to dichromate, it would be approximately i 83.5 times more colored than it is. At higher concentrations more and more dichromate is formed, but unchanged chromate also is present and this, if transformed to dichromate, would raise the color-ratio to 183.5 . Therefore, at any concentration, the percentage of dichromate in the chromate-dichromate mixture is equal to the color-ratio minus one, multiplied by Ioo $\div$ 183.5. In the fifth column of the table, I 80 was used as the factor instead of 183.5 . Since dichromates are acid in reaction, thus indicating the presence of free "chromic acid," which is more strongly colored than dichromates,

${ }^{1}$ For the above-indicated reasons, in solutions of 0.01 to $0.05 \%$ concentrations of chromate, difficulty was met with in matching colors. The densities of color, rather than the quality of color, were compared. Above $0.05 \%$ and below $0.01 \%$ the solutions gave no difficulty in reading. 
the correctness of factor I 80 can not be strictly maintained, though it probably is approximately correct. ${ }^{1}$

Sherrill" states that "in a 0.1 molal solution of potassium dichromate approximately $15 \%$ of the salt exists as hydrochromate and $85 \%$ as dichromate, while in a o.or molal solution approximately $45 \%$ exists in the former state." Now, o.I and o.or molal solutions of dichromate contain $52 \mathrm{~g}$. of chromium in 20 and 200 liters, respectively. As seen in the table, 15 and $45 \%$ of dichromate are contained in 107.29 and 147.53 liters, respectively. These approximations of values are interesting not only for the reason that Sherrill ${ }^{3}$ claimed no great accuracy, but also for the reason that he obtained his data by solubility experiments with silver chromate and dichromate. ${ }^{4}$

\section{The Transition-Concentration of Chromates and Dichromates.}

A study of Table I shows that at 0.01 and 0.10 concentrations at ordinary temperatures, chromates are transformed to dichromates-in other words, the mass action of water ${ }^{5}$ below these concentrations completely transforms dichromate to chromate.

Walden ${ }^{6}$ observed at $25^{\circ}$, in these same concentrations, abnormal electrical conductivities, which he could not explain. These are indicated by the asterisks in the following condensed table.

\begin{tabular}{|c|c|c|c|c|c|c|c|c|c|}
\hline \multirow{3}{*}{$\begin{array}{c}\text { Liters } \\
\text { containing } \\
52 \mathrm{~g} \text { of } \mathrm{Cr} \text {. }\end{array}$} & \multirow{3}{*}{$\begin{array}{c}\text { Recalc. } \\
\text { as \% of } \\
\mathrm{H}_{2} \mathrm{CrO}_{4}\end{array}$} & \multicolumn{6}{|c|}{ As $1 / 2$ molecules each of } & \multirow{2}{*}{\multicolumn{2}{|c|}{$\mathrm{Na}_{2} \mathrm{Cr}_{2} \mathrm{O}_{7}$}} \\
\hline & & \multicolumn{2}{|c|}{$\mathrm{K}_{3} \mathrm{Cr}_{2} \mathrm{O}_{7}$} & \multirow{2}{*}{$\underset{\mu .}{\mathrm{K}_{2} \mathrm{Cr}_{8} \mathrm{O}_{10}}$} & \multirow{2}{*}{$\underset{\mu}{2 \mathrm{H}_{2} \mathrm{CrO}_{4}}$} & \multicolumn{2}{|c|}{$\mathrm{K}_{9} \mathrm{CrO}_{4}$} & & \\
\hline & & $\mu$. & $10^{2} \Delta l / l$. & & & H. & $10^{2} \Delta d l l$. & $\mu$ & $10^{2} \Delta l / l$. \\
\hline 32 & 0.3687 & II 4.4 & . & $275 \cdot 9$ & $347 \cdot 1$ & $12 \mathrm{I} .2$ & . & 95.0 & \\
\hline 64 & 0.1843 & II6.6 & I. 830 & 282.9 & 354.7 & $127 \cdot 5$ & 5 & 96.5 & I. 580 \\
\hline 128 & 0.0922 & $\operatorname{II} 7.6$ & $0.85^{8}$ & $286 . \mathrm{I}$ & $35^{8.9}$ & $\mathrm{I} 32.2$ & 3.69 & 96.8 & 0.310 \\
\hline 256 & $0.0461 *$ & 118.0 & $0.340^{*}$ & $286.4^{*}$ & $361 \cdot 3^{*}$ & 136.1 & 2.95 & 97.0 & $0.207^{*}$ \\
\hline 512 & 0.0230 & 118.7 & 0.593 & 23 & 360.8 & 138.7 & $I .9 I$ & 97.7 & 0.722 \\
\hline 1024 & 0.0115 & 120.7 & 1.850 & 278.2 & 358.4 & 140.7 & I .44 & 98.8 & I. I 30 \\
\hline 2048 & 0.0057 & $\mathrm{I} 24 . \mathrm{I}$ & 2.650 & . . & $353 \cdot 7$ & $\ldots$ & $\ldots$ & 102.8 & 3.540 \\
\hline
\end{tabular}

Two important observations are made: (1) potassium chromate does not show abnormal conductivities within the range of concentations studied by Walden; (2) the others, all di- or tri-chromates, show abnormal con-

${ }^{1}$ See curves on pages following.

2 This Journar, 29, 1674 .

${ }^{8}$ Sherrill is the first investigator to recognize the $\mathrm{K}_{2} \mathrm{CrO}_{4} \rightleftarrows \mathrm{K}_{2} \mathrm{Cr}_{2} \mathrm{O}$ equilibrium in solutions of both chromates and dichromates.

4 Abegg and $\operatorname{Cox}(Z$. physik. Chem., 48, 425) considered that a dichromate solution contains mainly $\mathrm{CrO}_{4}{ }^{\prime \prime}$ ions and undissociated $\mathrm{K}_{2} \mathrm{CrO}_{4}$, while the concentration of $\mathrm{Cr}_{2} \mathrm{O}_{7}{ }^{\prime \prime}$ ions is small. See Spitalsky (Z. anorg. Chem., 53, $\left.184 ; 54,265\right)$ for opposite view. See also Lundberg, Ibid., 55, 426.

${ }^{5}$ Sherrill and Eaton (THIS JoUrNaI, 29, 1642). "If the dichromate ion becomes hydrated to form the hydrochromate ion, the condition most favorable for its formation would be in the more dilute solutions, according to the mass-action law."

- $Z$. anorg. Chem., I, 546; 2, 70 . 
ductivities at $0.046 \%$ concentrations, $i$. e., at the concentration wherein much transition ${ }^{1}$ takes place according to the reaction:

$$
\mathrm{H}_{2} \mathrm{Cr}_{2} \mathrm{O}_{7}+\mathrm{H}_{2} \mathrm{O} \rightleftarrows 2 \mathrm{H}_{2} \mathrm{CrO}_{4} \text {. }
$$

From spectra-absorption studies Hantzsch and $\mathrm{Clark}^{2}$ obtained the following data: ${ }^{3}$

\begin{tabular}{|c|c|c|c|c|c|c|}
\hline & & $\int_{7}$ & MOLS AC & $=48$ & & \\
\hline$i$ & $\begin{array}{l}\text { Recalc. as } \\
\% \% \mathrm{H}_{2} \mathrm{CrOO}_{4} .\end{array}$ & $\begin{array}{c}\text { In pure } \\
\mathrm{H}_{2} \mathrm{O} .\end{array}$ & $\begin{array}{c}\mathrm{N} / 2000 \\
\mathrm{CH}_{3} \mathrm{COOH} .\end{array}$ & $\mathrm{N} / \mathrm{H}_{2} \mathrm{SO}_{4}$ & $\begin{array}{l}\mathrm{N}_{2} 10 \\
\mathrm{SO}_{4}\end{array}$ & $\begin{array}{l}\text { In } 99 \% \\
\mathrm{H}_{2} \mathrm{SO}_{4}\end{array}$ \\
\hline 100 & 0.2360 & 88.7 & 90.9 & 90.9 & 90.5 & $9 \mathrm{I} .4$ \\
\hline 200 & 0.1180 & 87.0 & $90.0^{*}$ & $88.8^{*}$ & $90.0^{*}$ & $90 \cdot 5^{*}$ \\
\hline 500 & 0.0472 & $86.8^{*}$ & 90.4 & 89.3 & $90.7^{\prime}$ & 90.7 \\
\hline 1000 & 0.0236 & 87.2 & . & 90.4 & 91.2 & 91.2 \\
\hline 2000 & 0.0118 & 87.6 & $\ldots$ & 91.0 & $\ldots$ & . \\
\hline
\end{tabular}

Here as before it is observed: (I) that abnormal phenomena occur at $0.047 \%$ concentrations; (2) acid solutions require higher concentrations; (3) the data, instead of indicating no chromophoric variation, ${ }^{4}$ correlate with the conclusions of this contribution.

\section{The Mass of Water Dissociating Dichromates.}

Since a $0.01 \%$ concentration of potassium dichromate (calculated as per cent. of $\mathrm{H}_{2} \mathrm{CrO}_{4}$ ) is completely hydrolyzed to monochromate, $294.2 \mathrm{~g}$. of it will be hydrolyzed by $2,360,400 \mathrm{~g}$. of water or one molecule of potassium dichromate will be hydrolyzed by I3I,000 molecules of water. Since two molecules of alkali transform dichromates to chromates one molecule of alkali and 65,000 molecules of water have the same dissociating effect on dichromates.

\section{The Dichromate-Chromic Acid Color-Ratios.}

In the manner described above the data of Table II were obtained.

These experiments show that, for equal concentrations of chromium, chromic acid solutions are more colored than dichromate solutions. This can be accounted for either on the basis that the dichromate is more largely dissociated into the less-colored monochromate, or that the chromic acid is associated in more colored structures as:<smiles>O=C(O)O[Cl+3]([O-])([O-])O[Cl+3]([O-])([O-])O</smiles><smiles></smiles>

either of which structure is more deeply colored ${ }^{5}$ than the dichromate. That the latter view is the more probable follows from the fact that,

$1 \mathrm{Cf}$. data on pages following.

${ }^{2}$ Z. physik. Chem., 63, 373 .

${ }^{3} \mathrm{Cf}$. Sabatier, Compt. rend., 103, 49, 138, 267.

* See the contrary conclusions of Hantzsch and Clark, Z. physik. Chem., 63, 373.

s Hantzsch and Clark, Z. physik. Chem., 63, 377. 
TABLE II.

\begin{tabular}{|c|c|c|c|c|c|c|c|c|c|c|c|}
\hline \multirow[b]{2}{*}{ "ै } & \multicolumn{5}{|c|}{$\mathrm{CrO}_{3}: \mathrm{K}_{2} \mathrm{Cr}_{2} \mathrm{O}_{7}$} & \multicolumn{6}{|c|}{$\mathrm{CrO}_{3}: \mathrm{K}_{2} \mathrm{CrO}_{4}$} \\
\hline & $8^{\circ}$ & & 5 & & & $\breve{5}$ & 6 & & $\overline{6}$ & $\approx$ & \\
\hline 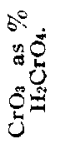 & 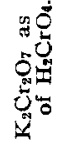 & 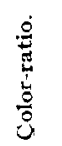 & 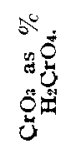 & 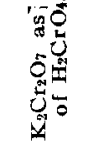 & 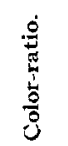 & 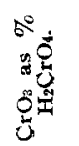 & 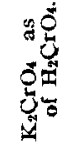 & 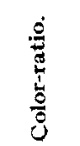 & 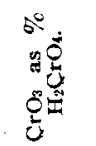 & 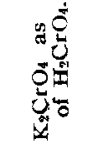 & 夤 \\
\hline 5.0 & I 3.0 & 2.60 & 0.500 & 0.6000 & I. 20 & 0.100 & 16.00 & 160.0 & 0.0060 & 0.0080 & I. 25 \\
\hline 4.5 & \2.0 & 2.66 & 0.400 & 0.5000 & I.20 & 0.090 & 12.00 & 133.0 & 0.0050 & 0.0070 & 1.40 \\
\hline 4.0 & 9.0 & 2.25 & 0.080 & 0.1000 & 1.25 & 0.080 & 10.00 & 125.0 & 0.0045 & 0.0050 & I. II \\
\hline 3.5 & 7.0 & 2.00 & 0.060 & 0.0700 & 1.16 & 0.070 & 8.00 & .0 & 0040 & 42 & 1.05 \\
\hline 3.2 & 6.0 & I. 87 & $0.05^{\circ}$ & 0.0600 & I. 20 & 0.060 & 6.50 & ro8.0 & .0040 & $4 I$ & 1.0 \\
\hline 3.0 & $5 \cdot 4$ & 1.80 & 0.035 & 0.0400 & I.1 4 & 50 & 5.00 & 100.0 & 1030 & 030 & 1.00 \\
\hline 2.9 & 5.0 & I. 72 & 0.008 & 0.0090 & 1,12 & 0.040 & 3.00 & 5.0 & 0.0020 & .0020 & 1.00 \\
\hline 2.5 & 4.0 & I. 60 & 0.007 & 0.0080 & 1.14 & 330 & $0.5^{\circ}$ & I 7.0 & 0.0010 & OIO & 1.00 \\
\hline I.3 & 2.0 & I. 54 & 0.006 & 0.0070 & I.16 & 0.020 & 0.10 & 5.0 & 209 & Dog & 1.00 \\
\hline 1.0 & I.4 & 1.40 & 0.004 & 0.0045 & 1.12 & 0.010 & 0.04 & 4.0 & 0.0008 & .0008 & 1.0 \\
\hline 0.8 & 1.0 & 1.25 & 0.003 & 0.0030 & 1.00 & 0.009 & 0.03 & 3.3 & 0.0007 & .0007 & 1.0 \\
\hline 0.7 & 0.9 & I. 28 & 0.002 & 0.0020 & 1.00 & 0.008 & 0.02 & 2.5 & 0.0006 & 0.0006 & 1.00 \\
\hline 0.65 & 0.8 & 1.23 & $0.00 \mathrm{I}$ & 0.0010 & 1.00 & 0.007 & 0.01 & I. I & 0.0005 & 0.0005 & $1 . \infty$ \\
\hline
\end{tabular}

in $0.2 \%$ solutions, the dichromate seems to reach a maximum colorratio of $\mathrm{I} 8 \mathrm{o}$, while the chromic acid is somewhat darker (color-ratio, 225) than the dichromate at this concentration, but steadily increases in higher concentrations until its color-ratio is twice that of the dichromate.

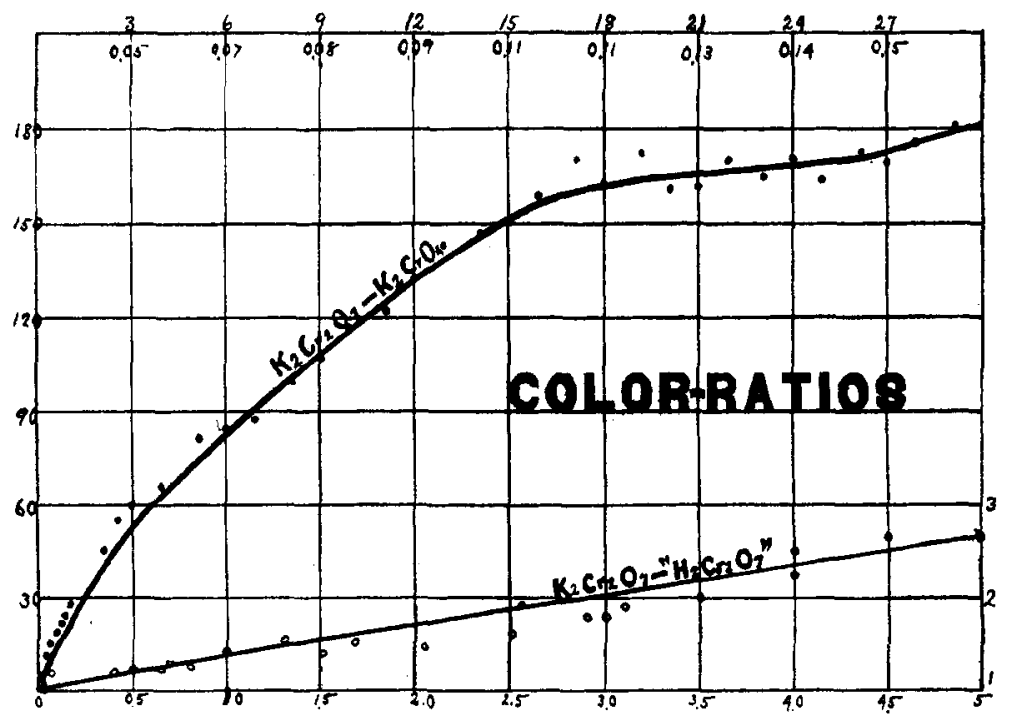

Plate I.

These curves were plotted from the data of Tables I and II. The ordinates are color-ratios; the abscissas are concentrations. It will be 
observed that the potassium dichromate indicates two phases in concentrations above $0.01 \%-(\mathrm{I})$ from 0.01 to $0.1 \%$ concentrations, the true dichromate phase; (2) above $0.1 \%$ probably $^{1}$ the trichromate phase, and possibly the tetrachromate phase.

The data of various investigators ${ }^{2}$ tend to prove the existence in aqueous solutions of dichromic acid ${ }^{3}$ only--the existence of tri-, tetra-, and monochromic acids were doubted. ${ }^{4}$ Since only moderately ${ }^{5}$ concentrated solutions were employed, most data pointed to the existence of the dichromic acid only.

Sherrill and Eaton ${ }^{6}$ made cryoscopic determinations of potassium dichromate and chromic acid solutions and calculated the van't Hoff factors, which are 3 for $\mathrm{K}_{2} \mathrm{Cr}_{2} \mathrm{O}_{7} \rightleftarrows 2 \mathrm{~K}+\mathrm{Cr}_{2} \mathrm{O}_{7}$, and 4 for $2 \mathrm{KHCrO}_{4} \rightleftarrows 2 \mathrm{~K}+$ $2 \mathrm{HCrO}_{4}$. The following quoted data have been condensed:

\begin{tabular}{ccc}
\multicolumn{3}{c}{$\mathrm{K}_{2} \mathrm{CrO}_{3}$} \\
$\begin{array}{c}\text { Molal conc. } \\
\text { in 1 liter. }\end{array}$ & $\begin{array}{c}\text { Recalc. as } \\
\text { of } \mathrm{H}_{2} \mathrm{CrO}_{4} .\end{array}$ & $\begin{array}{c}\text { van't Hoff } \\
\text { factor. }\end{array}$ \\
0.05340 & 1.2650 & 2.66 \\
0.04000 & 0.9440 & 2.74 \\
0.03680 & 0.8686 & 2.79 \\
0.02889 & 0.6819 & 2.88 \\
0.02760 & 0.6515 & 2.94 \\
0.02053 & 0.4839 & 2.98 \\
0.01743 & 0.4114 & 3.04 \\
0.01384 & 0.3267 & 3.16 \\
0.01105 & 0.2608 & 3.28 \\
0.00510 & 0.1204 & 3.70
\end{tabular}

\begin{tabular}{|c|c|c|}
\hline \multicolumn{3}{|c|}{$\mathrm{H}_{2} \mathrm{Cr}_{2} \mathrm{O}_{7}$} \\
\hline $\begin{array}{l}\text { Molal conc. } \\
\text { in } 1 \text { liter. }\end{array}$ & $\underbrace{\text { Recalc as }}_{\% \text { of } \mathrm{H}_{2} \mathrm{CrO}_{4} \text {. }}$ & $\begin{array}{l}\text { van't Hoff } \\
\text { factor. }\end{array}$ \\
\hline 0.10160 & 2.398 & 2.91 \\
\hline 0.07670 & 1.810 & 2.89 \\
\hline 0.07180 & I. 695 & 2.92 \\
\hline 0.06440 & I. 520 & 2.90 \\
\hline 0.05880 & I. 388 & 2.90 \\
\hline 0.04690 & I , 107 & 2.96 \\
\hline 0.03340 & 0.788 & 3.06 \\
\hline 0.02730 & 0.644 & 3.07 \\
\hline $0.0137^{\circ}$ & 0.323 & 3.26 \\
\hline 0.00958 & 0.226 & $3 \cdot 33$ \\
\hline
\end{tabular}

These data seem to prove that: (I) in very concentrated solutions both the dichromate and the chromic acid are incompletely ionized; (2) at about $0.4 \%$ concentration, the dichromate predominates; and (3) in very dilute solutions, the chromate predominates. However, if van't Hoff factors for all the chromic acids are calculated, we obtain the following:

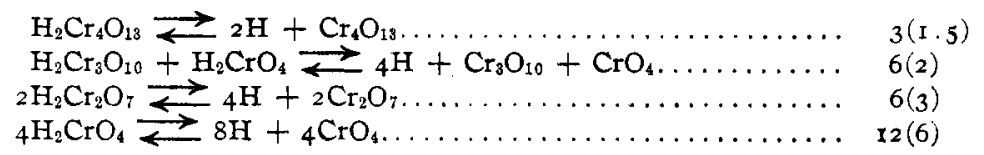

${ }^{1}$ Experiments with more soluble sodium dichromate and chromic acid by the methods of this contribution and other physical-chemical methods, to determine the presence of trichromic and tetrachromic acid phases in solutions of chromic oxide, will be undertaken in this laboratory.

2 See résumé above.

3 Costa's (Gazz. ital. chim., 36, 535) molecular-weight determinations by the boiling-point method, with quite concentrated solutions of chromic oxide, indicated its tendency to yield polychromates.

'See especially Walden, Z. physik. Chem., 2, 73.

${ }^{5}$ See especially Hantzsch and Clark, Ibid., 63, 373.

6 This Journal, 29, 1645. 
Here it may be seen that factors less than 3 may not only indicate nonionized molecules of the dichromate but also the formation of polychromates.

The Influence of an Excess of Alkali on Chromates.

Since potassium chromate is alkaline in reaction, thus indicating hydrolysis:

(a) $\mathrm{K}_{2} \mathrm{CrO}_{4}+\mathrm{H}_{2} \mathrm{O} \rightleftarrows \mathrm{KHCrO}_{4}+\mathrm{KOH}$

and since, in concentrated solutions, it undergoes condensation:

(b) $2 \mathrm{~K}_{2} \mathrm{CrO}_{4}+\mathrm{H}_{2} \mathrm{O} \rightleftarrows \mathrm{K}_{2} \mathrm{Cr}_{2} \mathrm{O}_{7}+2 \mathrm{KOH}$

thus, in both cases yielding free alkali, it may be expected to give colorvariations in the presence of different quantities of free alkali. This conclusion was verified by experiment.

\begin{tabular}{|c|c|c|c|c|c|}
\hline \multicolumn{3}{|c|}{$\mathrm{K}_{2} \mathrm{CrO}_{4}+\mathrm{KOH}$} & \multicolumn{3}{|c|}{$\mathrm{K}_{3} \mathrm{CrO}_{4}+6 \mathrm{KOH}$} \\
\hline $\begin{array}{l}\mathrm{K}_{8} \mathrm{CrO}_{4} \\
\text { as \%o of } \\
\mathrm{H}_{2} \mathrm{CrO}_{4}\end{array}$ & $\begin{array}{c}\mathrm{K}_{2} \mathrm{CrO}_{4}+\mathrm{KOH} \\
\begin{array}{c}\text { as }{ }_{6} \text { of } \\
\mathrm{H}_{2} \mathrm{CrO}_{4}\end{array}\end{array}$ & $\begin{array}{l}\text { Color- } \\
\text { ratio. }\end{array}$ & $\begin{array}{l}\mathrm{K}_{2} \mathrm{CrO}_{4} \\
\text { as \%o of } \\
\mathrm{H}_{2} \mathrm{CrO}_{4}\end{array}$ & $\begin{array}{c}\mathrm{K}_{2} \mathrm{CrO}_{4}+6 \mathrm{HOH} \\
\text { as \% of } \\
\mathrm{H}_{4} \mathrm{CrO}_{4} .\end{array}$ & $\begin{array}{l}\text { Color- } \\
\text { ratio. }\end{array}$ \\
\hline 13.0 & 23.0 & 1.78 & 5.5 & 8.0 & I. 45 \\
\hline I 2.6 & 19.0 & $1.5 \mathrm{I}$ & 5.0 & 7.0 & 1.40 \\
\hline I 2.0 & 17.0 & $\mathrm{I} .42$ & $4 \cdot 3$ & 6.0 & I.39 \\
\hline II.O & 15.0 & $1 \cdot 36$ & 4.0 & $5 \cdot 0$ & 1.25 \\
\hline 8.4 & 10.0 & I. I9 & $3 \cdot 4$ & 4.0 & I. II \\
\hline $7 \cdot 3$ & 8.0 & 1.09 & 3.0 & 3.0 & $1 . \infty$ \\
\hline 7.0 & $7 \cdot 5$ & 1.07 & 2.0 & 2.0 & $1 . \infty$ \\
\hline 7.0 & 7.0 & 1.00 & 1.0 & 1.0 & $1 . \infty$ \\
\hline 1.0 & I.O & $1 . \infty$ & 0.08 & 0.08 & $1 . \infty$ \\
\hline
\end{tabular}

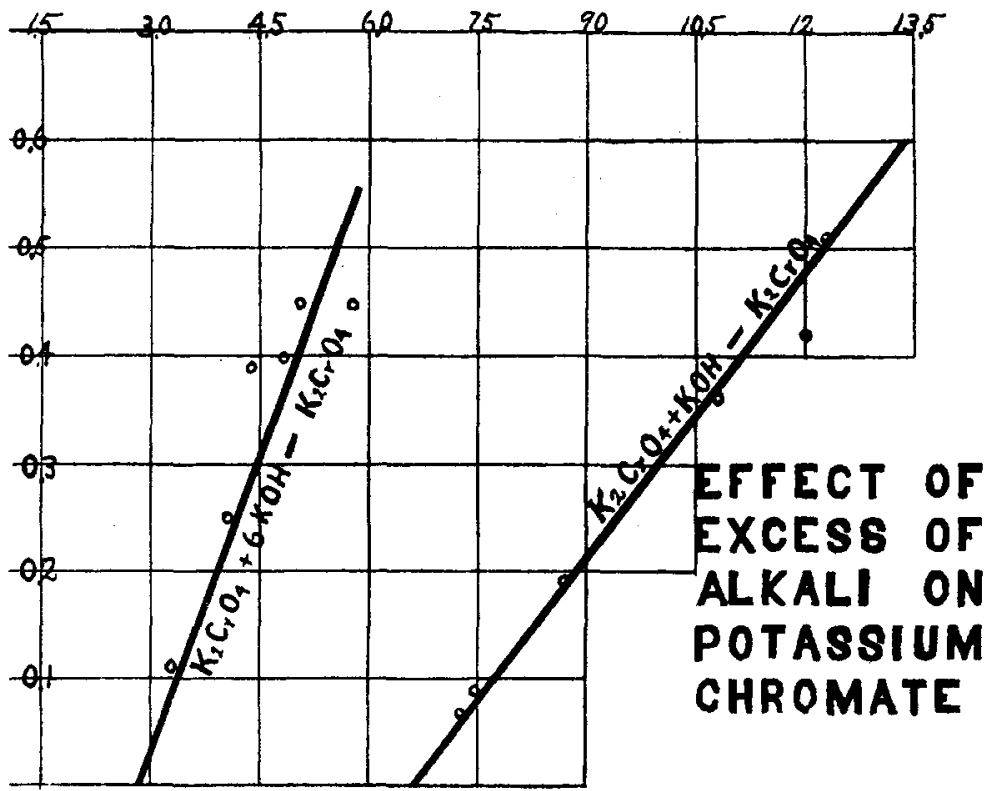

Plate II. 
These experiments show that: (I) definite color-variations are caused by an excess of alkali; (2) solutions of potassium chromate containing one molecule of alkali match the solutions containing only potassium chromate up to $7 \%$ concentrations; (3) solutions containing six molecules of alkali match the chromate solutions only up to $3 \%$ concentrations. This divergence at lower concentrations for the latter is to be expected, since, being more nearly monochromic than either of the other two solutions, it will show a color-difference throughout a wider range of concentrations.

These studies with alkali show that in moderately concentrated solutions chromates contain an appreciable quantity of dichromate, ${ }^{1}$ at least in solutions more concentrated than $3 \%$. By the use of the color-factor I 80 . and on the basis that the color-variations are caused by chromophoric changes as indicated in equation (b) above, it may be calculated that a $5 \%$ solution of "potassium chromate" contains chromate and dichromate in the ratio of 450 : I. Of course, more concentrated solutions contain more and more of the dichromate.

\section{The Influence of Heat on Chromate Solutions.}

Heating solutions of chromic acid, potassium dichromate, potassium chromate, and potassium chromate containing alkali, gives marked deeping of the colors. This phenomenon is difficult to explain except on the basis of dehydration change of chromophores in accordance with:

$$
\mathrm{H}_{2} \mathrm{CrO}_{4} \rightleftarrows \mathrm{H}_{2} \mathrm{Cr}_{2} \mathrm{O}_{7} \rightleftarrows \mathrm{H}_{2} \mathrm{Cr}_{3} \mathrm{O}_{10} \rightleftarrows \mathrm{H}_{2} \mathrm{Cr}_{4} \mathrm{O}_{13} \text {. }
$$

The following table includes data obtained by heating towel-covered bottles for 20 minutes in the steam of vigorously boiling water baths, and making immediate comparisons with room-temperature samples.

The first column indicates concentrations as per cent. of $\mathrm{H}_{2} \mathrm{CrO}_{4}$; the second columns, marked $(b)$, the readings at ordinary temperatures against equal colored dichromate solutions; the columns marked (at) and (bt), the readings of chromic acid and dichromate solutions matching the

TABLE IV.

Chromic acid (a).

\begin{tabular}{|c|c|c|c|c|c|c|c|c|c|}
\hline \multicolumn{7}{|c|}{ 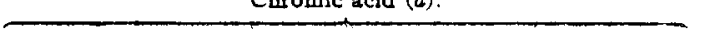 } & \multicolumn{3}{|c|}{$C_{2} U_{i}(0)$. } \\
\hline Per cent. & at. & $r$ & Per cent. . & $b$. & $b i$. & $r$. & Per cent. & bt. & $r$. \\
\hline 4.000 & $20+$ & $5+$ & $2 \cdot 30$ & 4,00 & I5.00 & $3 \cdot 7$ & $4 . \infty$ & 15.000 & $3 \cdot 7$ \\
\hline 3.000 & 15.00 & 5.0 & $1 . \infty$ & I. 40 & 5.00 & $3 \cdot 7$ & $2 . \infty$ & 7.000 & $3 \cdot 5$ \\
\hline 2.000 & 8.00 & 4.0 & 0.70 & 0.90 & 3.00 & $3 \cdot 3$ & $1 . \infty$ & $3 \cdot 500$ & $3 \cdot 5$ \\
\hline I. 500 & 5.00 & $3 \cdot 3$ & 0.60 & 0.70 & $2, \infty$ & 2.9 & 0.60 & 2.000 & $3 \cdot 3$ \\
\hline 0.800 & 2.00 & 2.5 & 0.20 & 0.20 & 0.40 & 2.0 & 0.20 & 0.500 & 2.5 \\
\hline 0.500 & 1.00 & 2.0 & 0.10 & o. 14 & 0.20 & 1.5 & 0.06 & 0.100 & 1. 6 \\
\hline 0.050 & 0.08 & 1.6 & 0.05 & 0.06 & 0.09 & I. 3 & 0.01 & 0.015 & 1.5 \\
\hline 0.009 & 0.01 & I . I & 0.02 & 0.03 & 0.04 & $1 \cdot 3$ & 0.0007 & 0.0008 & I. I \\
\hline
\end{tabular}

${ }^{1}$ See Hantzsch and Clark, Z. physik. Chem., 63, 374; Merrill, ThIs Journai, 29, 1650, I 66I. 


\begin{tabular}{|c|c|c|c|c|c|c|c|c|c|c|c|}
\hline \multicolumn{3}{|c|}{$\mathrm{K}_{2} \mathrm{CrO}_{4}(c)$} & \multicolumn{5}{|c|}{$\mathrm{K}_{2} \mathrm{CrO}_{4}+\mathrm{KOH}(d)}$. & \multicolumn{4}{|c|}{$\mathrm{K}_{2} \mathrm{CrO}_{4}+6 \mathrm{KOH}}$. \\
\hline Per cent. & $b$. & $b t$. & $r$ & Per cent. & $b$. & $b t$. & $r$ & Per cent. & $b$. & $b t$. & $r$ \\
\hline 29.0 & 0.16 & 0.80 & 5.0 & 19.0 & 0.09 & 0.600 & 6.5 & 8.0 & 0.065 & 0.40 & 6.I \\
\hline 20.0 & 0.12 & 0.55 & $4 \cdot 5$ & 10.0 & 0.08 & 0.300 & 3.7 & 4.0 & 0.060 & 0.25 & 4.2 \\
\hline I 8.0 & O.I I & 0.50 & 4.6 & 7.0 & 0.08 & 0.300 & $3 \cdot 7$ & 2.0 & 0.050 & 0.20 & 4.0 \\
\hline 10.0 & 0.08 & 0.30 & 3.7 & 5.0 & 0.06 & 0.200 & $3 \cdot 3$ & I.O & 0.025 & 0.07 & 2.8 \\
\hline 3.0 & 0.05 & 0.18 & 3.6 & 3.0 & 0.05 & 0.150 & 3.0 & 0.5 & 0.030 & 0.045 & I. 5 \\
\hline 1.0 & 0.04 & 0.08 & 2.0 & O.I & 0.009 & 0.200 & 2.2 & 0.4 & 0.040 & 0.05 & I. 2 \\
\hline 0.4 & 0.04 & 0.06 & $I .5$ & 0.01 & 0.007 & 0.009 & 1.3 & O.I & 0.070 & O.IO & I.4 \\
\hline 0.003 & 0.003 & 0.004 & 1.3 & 0.01 & 0.007 & 0.008 & I. I & 0.08 & 0.060 & 0.07 & I. 6 \\
\hline
\end{tabular}

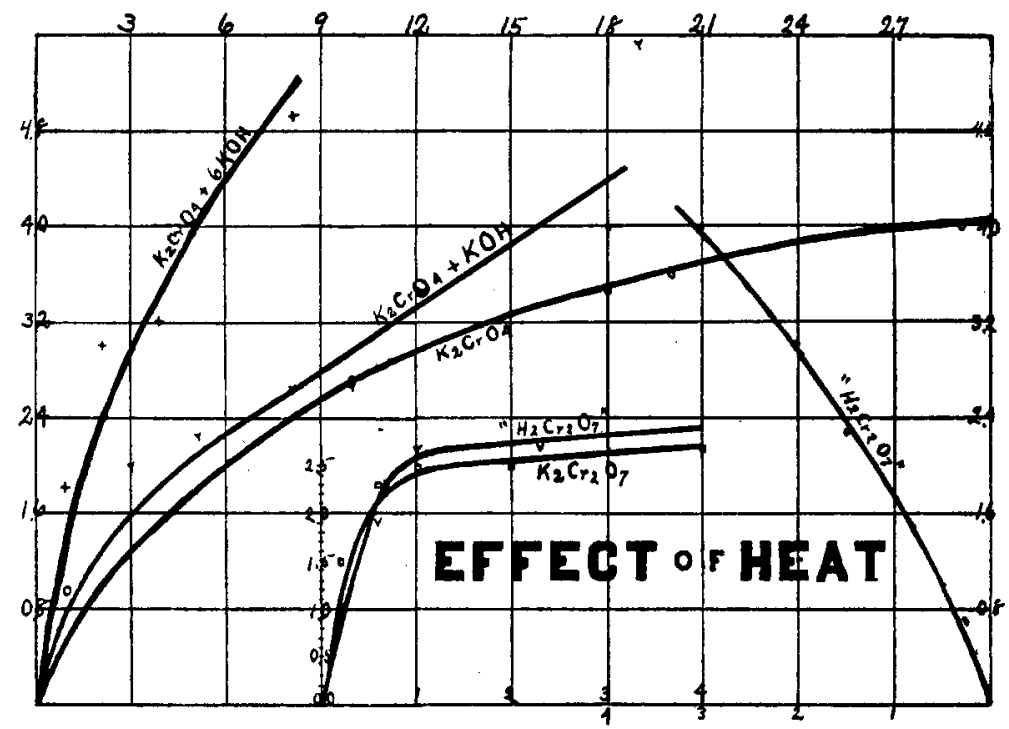

Plate III.

heated samples. The ratios of color ( $r$ ) of the cold and heated samples are calculated from the two columns immediately preceding columns $(r)$.

It is observed that an increase of about $80^{\circ}$ of temperature: ( $\mathrm{I}$ ) intensifies $^{1}$ the color of all these solutions from one to six times; (2) concentrated solutions give the largest change of color. This latter effect is to be expected since the mass-infuence of water and the influence of heat are opposite.

Preliminary experiments with picric acid, $o$-nitrophenol, their alkaline salts, both in cold and hot solutions, show variations of colors in varied concentrations, which indicate tautomeric changes, in accordance with the conclusions of Hantzsch. These substances will be studied by the methods of investigation of this contribution.

Solutions of chromates less concentrated than $0.001 \%$ are decolorized

${ }^{1}$ Hantzsch and Clark ( $Z$, physik. Chem., 63, 373) held that there is little or no effect of heat on chromate solutions as measured by light-absorption. Their data does uat justify this conclusion. 
on long standing in direct sunlight. This phenomenon will also be investigated.

\section{Summary.}

(1) Previous investigations have involved too limited a range of concentrations to elucidate the nature of chromate solutions.

(2) Hydrolytic equilibrium-changes involve color-changes; hydrationequilibria, though less important, also cause color-changes; ionizationequilibria, except as involving hydrolysis or hydration, probably have no effect on color-changes.

(3) Heat has marked effects on colors.

(4) Varied quantities of acids and alkalies have very important effects on the colors of chromates.

(5) Very dilute solutions of all chromates $\left(\mathrm{CrO}_{3}, \mathrm{H}_{2} \mathrm{CrO}_{4}, \mathrm{H}_{2} \mathrm{Cr}_{2} \mathrm{O}_{7}\right.$, $\left.\mathrm{H}_{2} \mathrm{Cr}_{3} \mathrm{O}_{10}, \mathrm{H}_{2} \mathrm{Cr}_{4} \mathrm{O}_{13}\right)$ contain only chromate molecules or ions.

(6) More concentrated solutions contain both $\mathrm{H}_{2} \mathrm{CrO}_{4}$ and $\mathrm{H}_{2} \mathrm{Cr}_{2} \mathrm{O}_{7}$ molecules and ions; chromate solutions contain dichromates and vice versa.

(7) At still greater concentrations or in acid solutions or when heated, dichromates contain trichromates and, probably at still greater concentrations, trichromates contain tetrachromates.

(8) Below the chromate-dichromate transition concentration, hydrated forms of chromate exist and probably produce color-variations.

Seattle, Wash.

[CONTRIBUtion FROM THE ChEMICAL LABORATORY OF THE UNIVERSITY OF ILIINOIS.]

\section{THE IDEAL DIFFUSION COEFFICIENT AND A FUNDAMENTAL LAW CONCERNING THE DIFFUSION OF DISSOLVED SUBSTANCES IN LIQUIDS.

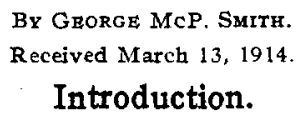

Introduction.

The significance of the diffusion coefficient $D$ is derived from the formula,

$$
d S=-D q \frac{d c}{d x} d t,
$$

in which $d S$ is the quantity of the dissolved substance which passes at the point $x$ in the time $d t$ through the cross-section $q$ of a diffusion cylinder under the influence of the concentration-fall $d c / d x$. The value of $D$ depends upon the temperature and upon the actual concentration.

If we consider an ideal diffusion cylinder of unit cross-section, $1 \mathrm{~cm} .{ }^{2}$, in which the concentration difference $I$ exists in the solution between two horizontal planes $I$ centimeter apart, and in which the solution in the plane half-way between these has the concentration $c$, then the con- 